\title{
Capabilities of Correlation-Regression Analysis for Forecasting of Value Added Tax
}

\section{Margarita S. Irizepova}

\author{
Ph.D., Associate Professor of the Chair of Finance, Credit, and Taxation, Volgograd State University \\ 100 Universitetskiy Ave., Volgograd, 40064, Russian Federation; irizepova@mail.ru
}

\section{Doi:10.5901/mjss.2016.v7n1p24}

\begin{abstract}
This article is devoted to description of peculiarities of forecast of VAT ("invoiced VAT" and "paid VAT") with the help of indicators of tax statistics and correlation-regression analysis. The offered method of forecasting allows determining the values of VAT indicators in the long term in connection with expected values of GDP. Demonstration of the method is presented by calculations of indicators "invoiced VAT" and "paid VAT" for 2015-2025 on the basis of official statistical information for 20062014.
\end{abstract}

Keywords: tax forecast, forecast of VAT, correlation-regression analysis, connection of VAT and GDP, methods of VAT forecasting.

\section{Introduction}

Value added tax constitutes the greater part of tax revenues into the state budgets of various countries. Russia is not an exception. Methods of forecast of taxes are studied by theorists and practitioners of taxation. The forecast of taxes, including VAT, uses formalized methods, including two subgroups: extrapolation (for example, least-square method, exponential smoothing, and sliding average) and modeling (with econometric (macro-economic and statistical) models and methods which allow receiving very precise forecasts). [Astafyeva E., Saakyan, 2007].

Scientific literature includes a lot of mentions of high complexity of VAT forecasting. This tax depends on the great number of factors which form value added. These include different tax rates depending on product type, form of activities of taxpayers (production, retail, public catering), etc. [Barulin, Ermakova, Stepanenko, 2007].

As a rule, the following approaches during the forecast of the volume of VAT revenues into the budget system are used:

- $\quad$ based in the evaluation of the share of tax revenues in GDP;

- based on indexing of tax revenues of previous periods;

- direct forecast of tax base;

- method of summarizing of predicted sums of separate taxes [Lermontov, 2004; Anisimov, Ostapenko, Pogorelko, 2003].

According to the Budget Code of the RF, the predicted volume of GDP is the primary macro-economic indicator for the formation of main characteristics of the federal budgets and main directions of development of budget and tax policies of the Russian Federation [Budget Code of the RF]. That's why many authors think that it is impossible to solve the problems of forecasting the tax revenues without consideration of the problems of GDP forecasting [Anisimov, Ostapenko, Pogorelko, 2003]. While agreeing fully with this statement, we think that there is a possibility to solve them partially, using correlation-regression analysis of indicators of VAT and GDP. Our studies show that building the forecast of VAT revenues into the budget requires the consideration of the planned (predicted) values of GDP. It is known that correlation-regression analysis is used in various spheres of science. However, the possibility of its use for solving the tasks of forecasting the taxes, including VAT, is not studied yet. Filling this gap, we have used this method for building the forecasts of two statistical indicators - "invoiced VAT" and "paid VAT" - for 2015-2025 in the RF, on the basis of statistical information for 2006-2014. The research showed good results. The method that we recommend is simple and accessible for scientists and practitioners which deal with the issues of planning of taxation indicators in the long term. Besides, the value of this method is determined by possibility for forecasting the indicators of VAT revenues into the budget, using the minimal informational resources, which increases not only objectiveness but the speed of getting the forecast. 


\section{Main Part}

\subsection{Setting the task}

Theoretical basis of the research is comprised of the works of modern authors in the sphere of tax accounting: (Anisimov et al., 2003), (Astafyeva \& Saakyan, (2007), (Barulin et al., 2007), (Grishchenko, 2013), (Korostelkina, 2011), (Kremer \& Putko, 2015), (Lermontov, 2004), (Okun A.S., 2015), (Protasov, 2012), (Ryabkov, 2015), (Slepneva, 2012), (Timirkhaniva \& Zhuravleva, 2013), and (Cherkharova, 2010).

Literature review showed that in modern theory of taxation, there is no connection between VAT and GDP. Thus, the purpose of this article is to determine the dependence between "paid / accrued" VAT and GDP and to build forecast model of development of the level of VAT until 2025.

Methodology of conduct of the research in this article is based on correlation-regression analysis. The reason for using this method is the fact that this method is optimal for determining interconnection and interdependence of the studied indicators and allows determining values of indicators of VAT in long-term, in interconnection with forecast values of GDP.

Using correlation-regression analysis in pairs for two VAT indicators ("invoiced VAT" and "paid VAT") with planned values of GDP, which are in the forecast of long-term socio-economic development of the RF until 2030, we have built predicted values of financial indicators "paid VAT" and "invoiced VAT".

The source of the data for calculations is the official state statistical information in the sphere of national finances and taxes. The set tasks were solved with the use of the methods of correlation-regression, economic, factor, comparative, dynamic, and statistical analysis, as well as methods of data processing in the programs STATISTICA Data Miner and Microsoft Office Excel.

The empirical basis for the research was the information from printed media and the Internet resources, specialized publications, and laws of the RF. Substantiation of main provisions of the described methods is provided by statistical and analytical materials of the Federal Tax Service of the RF and the Federal State Statistics Service.

Correlation-regression analysis of the GDP and VAT for 2006-2014 has been conducted in two directions:

- VAT is viewed in reports as paid tax for each year;

- VAT is viewed in reports as invoiced (difference between accrued tax and the tax refunded from the budget for a year, i.e., invoiced VAT for payment for a year).

Based on the received results, the comparative analysis has been conducted and conclusions have been made.

During the creation of the model that is used for evaluation of indicators of connections between VAT and GDP, GDP is presented as the influencing factor (factor $\mathrm{X}$ ), and VAT - as resulting factor (factor $\mathrm{Y}$ ).

\subsection{Determining the connection between GDP and "paid VAT" for 2006-2014}

Based in the official statistical information of the Federal State Statistics Service of the RF for 2006 - 2014, we have built statistical rows of two indicators - "paid VAT" (factor Y) and GDP (factor X) (Table 1).

Table 1 - Statistical rows "paid VAT" and GDP of the RF for 2006-2014

\begin{tabular}{|c|c|c|}
\hline Year & Sum of VAT (factor Y), RUB billion & Sum of GDP (factor X), RUB billion \\
\hline 2006 & 1.452 & $21,609.80$ \\
\hline 2007 & 1.208 & $33,247.50$ \\
\hline 2008 & 1.204 & $41,276.85$ \\
\hline 2009 & 1.234 & $38,807.22$ \\
\hline 2010 & 1.418 & $46,308.54$ \\
\hline 2011 & 1.680 & $55,967.23$ \\
\hline 2012 & 1.666 & $62,146.99$ \\
\hline 2013 & 1.867 & $66,193.74$ \\
\hline 2014 & 2.091 & $70,975.77$ \\
\hline
\end{tabular}

Source: [Tax statistics and analytics, 2014] 
Graphical presentation of these indicators points at linear correlation (regression) dependence between variables $\mathrm{X}$ and $\mathrm{Y}$ (Fig. 1).

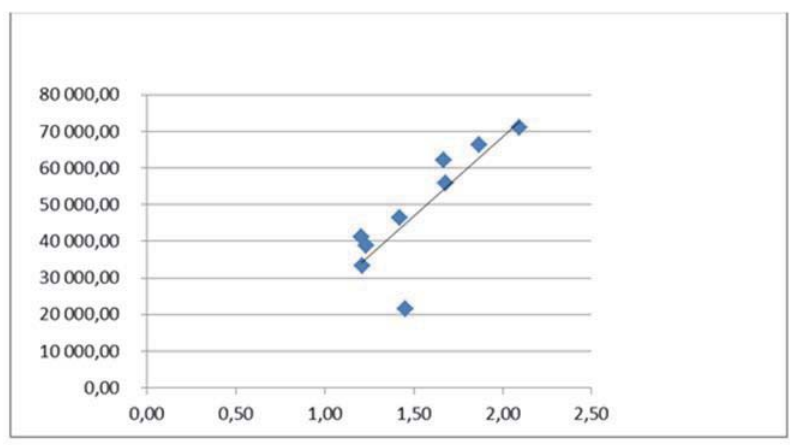

Figure 1 - Field of correlation of GDP of the RF and paid VAT for 2006-2014

That's why the equation of regression will be found in the form of linear equation [Kremer, 2015]:

$\tilde{y}=b_{0}+b_{1} * x, \quad(1)$

where $\tilde{y}$ - values $y$, found by regression equation;

$b_{0}, b_{1}$ - parameters of equation of regression, found by ratios:

$b_{0}=\bar{y}-b_{1} * \bar{x}(2)$,

$b_{1}=\frac{\overline{x y}-\bar{x} * \bar{y}}{\overline{x^{2}}-\bar{x}^{2}}(3)$

where, $\overline{x y}$ - average value of product of $X$ and $Y$.

Table 2 shows the received parameters of regression equation.

Table 2 - Data for conduct of regression analysis of paid VAT and GDP of the RF for 2006-2014

\begin{tabular}{|l|c|c|}
\hline Indicator & Formula for calculation & Value \\
\hline $\bar{y}$, RUB billion & $\left(\sum y\right) / n$ & 1.54 \\
\hline $\bar{x}$, RUB billion & $\left(\sum x\right) / n$ & $48,503.74$ \\
\hline$\overline{x y}$, RUB billion & \\
\hline $\bar{x}^{2}$, RUB billion $^{2}$ & $\left(\sum(x * y)\right) / n$ & $78,280.27$ \\
\hline $\bar{x}^{2}$, RUB billion $^{2}$ & $\left(\sum x^{\wedge} 2\right) / n$ & $2,593,376,422.70$ \\
\hline
\end{tabular}

Then we receive the following parameters of linear regression:

$b_{0}=0.774$;

$b_{1}=0.00001571$.

The general form of functional dependence between sums received by the budget of the RF from taxation with value added $(\mathrm{Y})$ and sums of GDP $(\mathrm{X})$ is the following:

$\tilde{y}=0.774+0.00001571 * x$. (4)

Coefficient of regression $\left(b_{1}\right) \mathrm{Y}$ of $\mathrm{X}$ shows, by how many points in average the variable $\mathrm{Y}$ changes with the growth of the variable $X$ by one point. Calculations show that the increase of GDP (factor $X$ ) by RUB 1 billion leads to the growth of paid VAT (factor Y) by only RUB 15,710 $(0.00001571 \cdot$ RUB 1 billion. $=15,710)$

Evaluation of closeness of connection between GDP and VAT on the basis of the least-square method is determined by the coefficient of correlation. The attributes of this coefficient are the following:

- coefficient of correlation can adopt values on the period [-1;1]; the closer to 1, the closer the connection;

- if the correlation coefficient adopts values +1 or -1 , correlation connection is a linear functional dependence, and all observed values are situated on a straight line;

- $\quad$ at zero value of correlation coefficient, linear connections is absent [Kremer, 2015].

The value of correlation coefficient equal to 0.9282 shows a direct and strong connection of these two indicators (with the increase of GDP, VAT also grows). 
Table 3 - Calculation of correlation coefficient of GDP of the RF and paid VAT

\begin{tabular}{|l|c|c|}
\hline Indicator & Formula for calculation & Value \\
\hline Mean square deviation, RUB billion & $\sigma_{x}=\sqrt{\frac{1}{n} * \sum\left(x_{i}-\bar{x}\right)^{2}}$ & $\begin{array}{c}\sigma_{x}=15,516.57 \\
\sigma_{y}=0.29543\end{array}$ \\
\hline Covariance coefficient, RUB billion ${ }^{2}$ & $\operatorname{cov}_{x y}=\sigma_{x y}=\frac{\sum\left(x_{i}-\bar{X}\right) *\left(Y_{i}-\bar{Y}\right)}{n-1}$ & $4,254.69$ \\
\hline Correlation coefficient & $P_{x y}=\frac{\sigma_{x y}}{\sigma_{x} * \sigma_{y}}$ & 0.9282 \\
\hline
\end{tabular}

\subsection{Determining the connection between GDP and "invoiced VAT" for 2006-2014}

Table 4 - Statistical rows of invoiced VAT and GDP of the RF for 2006-2014 1

\begin{tabular}{|c|c|c|}
\hline Year & Volume of invoiced VAT (factor Y), RUB billion & Volume of GDP (factor X), RUB billion \\
\hline 2006 & 12.40 & $21,609.80$ \\
\hline 2007 & 15.62 & $33,247.50$ \\
\hline 2008 & 16.98 & $41,276.85$ \\
\hline 2009 & 17.29 & $38,807.22$ \\
\hline 2010 & 19.68 & $46,308.54$ \\
\hline 2011 & 24.97 & $55,967.23$ \\
\hline 2012 & 29.09 & $62,146.99$ \\
\hline 2013 & 30.93 & $66,193.74$ \\
\hline 2014 & 32.94 & $70,975.77$ \\
\hline
\end{tabular}

Source: [Tax statistics and analytics, 2014]

Graphical presentation of these indicators shows the presence of linear correlation (regression) dependence between variables $X$ and $Y$ (Fig. 2).

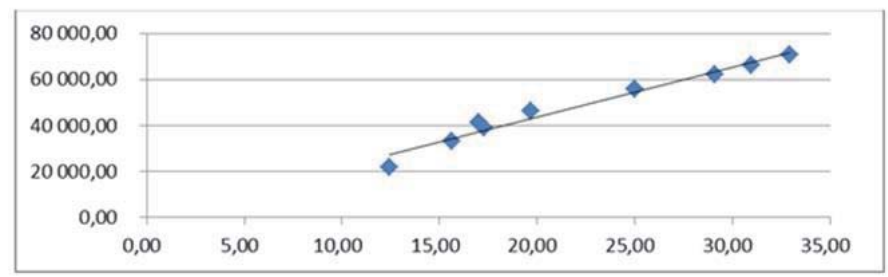

Figure 2 - Field of correlation of invoiced VAT and GDP of the RF for 2006-2014

Table 5 shows the received parameters of regression equation.

Table 5 - Data for conduct of regression analysis of invoiced VAT and GDP of the RF for 2006-2014

\begin{tabular}{|l|c|c|}
\hline Indicator & Formula for calculation & Value \\
\hline $\bar{y},($ RUB billion $)$ & $\left(\sum y\right) / n$ & 22.21 \\
\hline $\bar{x},($ RUB billion $)$ & $\left(\sum x\right) / n$ & $48,503.74$ \\
\hline$\overline{x y}$, RUB billion & \\
\hline $\bar{x}^{2}$, RUB billion $^{2}$ & $\left(\sum(x * y)\right) / n$ & $1,184,571.38$ \\
\hline $\bar{x}^{2}$, RUB billion $^{2}$ & $\left(\sum x^{\wedge} 2\right) / n$ & $2,593,376,422.70$ \\
\hline
\end{tabular}

Then, the regression equation has the following form:

\footnotetext{
1 Tax statistics and analytics [E-source] / Official page of the Federal Tax Service URL: http://www.nalog.ru/rn34/ Date of access
} 11.04.2014 
$\tilde{y}=0.604+0.000445 * x .(18)$

The conduct of correlation analysis requires calculation of the parameters shown in Table 6.

Table 6 - Calculation of coefficient of correlation of invoiced VAT and GDP of the RF for 2006-2014

\begin{tabular}{|l|c|c|}
\hline Indicator & Formula for calculation & Value \\
\hline Square-mean deviation, RUB billion & $\sigma_{x}=\sqrt{\frac{1}{n} * \sum\left(x_{i}-\bar{x}\right)^{2}}$ & $\begin{array}{c}\sigma_{x}=15,516.57 \\
\sigma_{y}=7.021\end{array}$ \\
\hline Co-variation coefficient, RUB billion ${ }^{2}$ & $\operatorname{cov}_{x y}=\sigma_{x y}=\frac{\sum\left(x_{i}-\bar{X}\right) *\left(Y_{i}-\bar{Y}\right)}{n-1}$ & $120,662.024$ \\
\hline Correlation coefficient & $P_{x y}=\frac{\sigma_{x y}}{\sigma_{x} * \sigma_{y}}$ & 0.9844 \\
\hline
\end{tabular}

Correlation coefficient equals 0.9844 , which proves direct and close connection of two indicators.

Table 7 - Values of coefficients of correlation of GDP and "paid VAT", GDP and "invoiced VAT"

\begin{tabular}{|l|c|}
\hline Indicators & Coefficient of correlation, in unit fractions \\
\hline GDP and "paid VAT" & 0.9282 \\
\hline GDP and "invoiced VAT" & 0.9844 \\
\hline
\end{tabular}

Comparative analysis of the received values of coefficients shows stronger connection between GDP and "invoiced VAT" than with "paid VAT", which proves multiple conclusions of the Russian researchers regarding problems with administration of this tax in Russia.

\subsection{Building forecast of indicators of "paid VAT" and "invoiced VAT" in Russia for 2015-2025}

Table 8 shows the data of predicted values of GDP according to the forecast of long-term socio-economic development of the Russian Federation until 2030 [Forecast of long-term socio-economic development of the Russian Federation until 2030, 2015].

Table 8 - Indicators of annual average rates of growth of GDP of the Russian Federation for 2015-2030 (as \%)

\begin{tabular}{|l|c|c|c|c|c|}
\hline Indicator & Variants & $2016-2020$ & $2021-2025$ & $2026-2030$ & $2013-2030$ \\
\hline \multirow{3}{*}{ Gross domestic product of the RF } & 1 & 3.6 & 3.0 & 2.5 & $3.0-3.2$ \\
& 2 & 4.4 & 4.0 & 3.7 & $4.0-4.2$ \\
& 3 & 6.8 & 5.3 & 4.2 & $5.0-5.4$ \\
\hline
\end{tabular}

Source: [Forecast of long-term socio-economic development of the Russian Federation until 2030, 2015]

Indicator of the growth of GDP is forecasted in view of many factors; depending on the level of implementation of these factors, three scenarios of socio-economic development in the long term are possible - (1) conservative, (2) innovational and (3) targeted (forced).

Conservative scenario is characterized by moderate long-term rates of growth of economy on the basis of active modernization of energy and raw sector of the Russian economy with preservation of relative underrun in civil high-tech and medium-tech sectors. Modernization of economy is oriented mostly at imported technologies and knowledge. At that, average annual rates of growth of GDP are evaluated at the level of 3.0-3.2\% for 2015-2030. The economy will grow until 2030 only by 1.7 times, and real income of population will grow by 1.9 times, while the share of Russia in the global GDP will reduce from $3.8 \%$ in 2012 to $3.6 \%$ in 2030 .

Innovational scenario is characterized by strengthening of investment direction of economic growth. The scenario is based on creation of modern transport infrastructure and competitive sector of high-tech productions and economy of knowledge, together with modernization of energy and raw complex. The scenario supposes turning the innovational factors into the leading source of economic growth and breakthrough in the increase of effectiveness of human capital on the brink of 2020-2022, which allows improving social parameters of development. Average annual rates of growth of the Russian economy are evaluated at the level of $4.0-4.2 \%$ in $2015-2030$, which will exceed the growth of the global 
economy and will allow increasing the Russia's share of the global GDP to 4.3\% by 2030.

Targeted (focused) scenario is developed on the basis of innovational scenario; at that, it is characterized by forced rates of growth, increased norm of accumulation of private business, creation of large-scale non-energy export sector, and significant inflow of foreign capital. The scenario supposes full-scale realization of all tasks set in the decrees of the President of the Russian Federation dated May 7, 2012, No. 596-606 [11]. Average annual growth rates of GDP rise by $5.0-5.4 \%$, which increases the share of the Russian economy in the global GDP to $5.3 \%$ of the global GDP by 2030.

As is seen from the data of Table 8, there the level of the growth of GDP is very scattered depending on the chosen method. In order to build the forecast of the indicators of VAT, we use the data of the second variant of development of the Russian economy. The basis will be the values of predicted GDP for 2015, as short-term forecast is more precise. As a result, we have the following picture of the predicted values of GDP for 2015-2025.

Table 9 - Predicted volumes of GDP for 2015 - 2025 according to innovational scenario of development of the Russian economy in view of the forecast of long-term socio-economic development of the RF until 2030

\begin{tabular}{|c|c|c|c|c|c|c|}
\hline \multirow{2}{*}{ Years } & \multicolumn{2}{|c|}{ Conservative scenario } & \multicolumn{2}{c|}{ Innovational scenario } & \multicolumn{2}{c|}{ Forced scenario } \\
\cline { 2 - 7 } & Growth of GDP, \% to previous year & GDP, RUB billion & $\begin{array}{c}\text { Growth of GDP, \% } \\
\text { to previous year }\end{array}$ & $\begin{array}{c}\text { GDP, RUB } \\
\text { billion }\end{array}$ & $\begin{array}{c}\text { Growth of GDP, \% } \\
\text { to previous years }\end{array}$ & $\begin{array}{c}\text { GDP, RUB } \\
\text { billion }\end{array}$ \\
\hline 2015 & 3.60 & $81,824.98$ & 4.40 & $82,937.00$ & 6.80 & $83,410.74$ \\
\hline 2016 & 3.60 & $84,443.38$ & 4.40 & $86,586.23$ & 6.80 & $87,748.10$ \\
\hline 2017 & 3.60 & $87,145.57$ & 4.40 & $90,396.02$ & 6.80 & $92,311.00$ \\
\hline 2018 & 3.60 & $89,934.23$ & 4.40 & $94,373.45$ & 6.80 & $97,111.17$ \\
\hline 2019 & 3.60 & $92,812.12$ & 4.40 & $98,525.88$ & 6.80 & $102,160.95$ \\
\hline 2020 & 3.60 & $95,782.11$ & 4.40 & $102,861.02$ & 6.80 & $107,473.32$ \\
\hline 2021 & 3.00 & $98,847.14$ & 4.00 & $106,975.46$ & 5.30 & $113,061.93$ \\
\hline 2022 & 3.00 & $102,010.24$ & 4.00 & $111,254.48$ & 5.30 & $118,941.16$ \\
\hline 2023 & 3.00 & $105,274.57$ & 4.00 & $115,704.66$ & 5.30 & $125,126.10$ \\
\hline 2024 & 3.00 & $108,643.36$ & 4.00 & $120,332.84$ & 5.30 & $131,632.65$ \\
\hline 2025 & 3.00 & $112,119.95$ & 4.00 & $125,146.16$ & 5.30 & $138,477.55$ \\
\hline
\end{tabular}

According to the forecasts of the Ministry of Finances of the RF, the following volumes of GDP are expected until 2017 Table10.

Table 10 - Predicted volumes of GDP for 2014 - 2017

\begin{tabular}{|l|c|c|c|c|}
\hline Indicator & 2014 & 2015 & 2016 & 2017 \\
\hline GDP, RUB billion & 73,315 & 82,937 & 86,837 & 89,834 \\
\hline
\end{tabular}

Source: [Federal law, 2013]

As is seen, short-term forecast of the Ministry of Finances for 2015 and the planned period of 2016 and 2017 conforms to the data of Table 9 for the given years.

Using the quantitative indicators of the connection of GDP with "pair VAT" and "invoiced VAT" and having predicted values of GDP (Table 9), let us build the forecast of financial indicators for VAT until 2025 года (Table 11).

Table 11 - Predicted values of "invoiced VAT" and "paid VAT" for 2015-2025 in case of innovational scenario of development of the Russian economy

\begin{tabular}{|c|c|c|c|c|c|c|c|c|c|c|c|c|}
\hline & \multicolumn{4}{|c|}{ Conservative scenario } & \multicolumn{4}{|c|}{ Innovational scenario } & \multicolumn{4}{|c|}{ Forced scenario } \\
\hline \multirow[t]{2}{*}{ Years } & \multicolumn{2}{|c|}{ "Invoiced VAT" } & \multicolumn{2}{|c|}{ "Paid VAT" } & \multicolumn{2}{|c|}{ "Invoiced VAT" } & \multicolumn{2}{|c|}{ "Paid VAT" } & \multicolumn{2}{|c|}{ "Invoiced VAT" } & \multicolumn{2}{|c|}{ "Paid VAT" } \\
\hline & RUB billion & $\begin{array}{c}\text { Growth } \\
\text { rate as to } \\
2015, \%\end{array}$ & RUB billion & $\begin{array}{l}\text { Growth } \\
\text { rate as to } \\
2015, \%\end{array}$ & $\begin{array}{l}\text { RUB } \\
\text { billion }\end{array}$ & $\begin{array}{c}\text { Growth } \\
\text { rate as to } \\
2015, \%\end{array}$ & $\begin{array}{l}\text { RUB } \\
\text { billion }\end{array}$ & $\begin{array}{l}\text { Growth } \\
\text { rate as to } \\
2015, \%\end{array}$ & $\begin{array}{l}\text { RUB } \\
\text { billion }\end{array}$ & $\begin{array}{l}\text { Growth } \\
\text { rate as to } \\
2015, \%\end{array}$ & $\begin{array}{l}\text { RUB } \\
\text { billion }\end{array}$ & $\begin{array}{l}\text { Growth } \\
\text { rate as to } \\
2015, \%\end{array}$ \\
\hline 2015 & 37.02 & 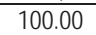 & 6 & 100.00 & 37.51 & 100.00 & .08 & 100.00 & 37.72 & 100.00 & .08 & 100.00 \\
\hline 2016 & 38.33 & $\overline{10}$ & 1 & 102 & 39.13 & 104 & 2.13 & 102.76 & 40.25 & 106.69 & 2.17 & 104.27 \\
\hline 2017 & 39.68 & 107.21 & 15 & 104.57 & 40.83 & 108.85 & 2.19 & 105.64 & 42.94 & 113.84 & 2.27 & 108.84 \\
\hline 2018 & 41.09 & 111.01 & 2.20 & 106.99 & 42.60 & 113.57 & 2.26 & 108.65 & 45.82 & 121.47 & 2.37 & 113.72 \\
\hline
\end{tabular}




\begin{tabular}{|l|l|l|l|l|l|l|l|l|l|l|l|l|}
\hline 2019 & 42.55 & 114.95 & 2.25 & 109.49 & 44.45 & 118.49 & 2.32 & 111.79 & 48.90 & 129.62 & 2.48 & 118.92 \\
\hline 2020 & 44.06 & 119.03 & 2.31 & 112.07 & 46.38 & 123.64 & 2.39 & 115.07 & 52.18 & 138.33 & 2.59 & 124.49 \\
\hline 2021 & 45.36 & 122.55 & 2.35 & 114.31 & 48.21 & 128.52 & 2.45 & 118.18 & 54.91 & 145.57 & 2.69 & 129.12 \\
\hline 2022 & 46.71 & 126.18 & 2.40 & 116.61 & 50.11 & 133.59 & 2.52 & 121.42 & 57.79 & 153.20 & 2.79 & 133.99 \\
\hline 2023 & 48.09 & 129.91 & 2.45 & 118.98 & 52.09 & 138.87 & 2.59 & 124.79 & 60.82 & 161.24 & 2.90 & 139.12 \\
\hline 2024 & 49.51 & 133.76 & 2.50 & 121.42 & 54.15 & 144.36 & 2.66 & 128.29 & 64.01 & 169.70 & 3.01 & 144.53 \\
\hline 2025 & $\mathbf{5 0 . 9 8}$ & $\mathbf{1 3 7 . 7 3}$ & $\mathbf{2 . 5 5}$ & $\mathbf{1 2 3 . 9 4}$ & $\mathbf{5 6 . 2 9}$ & $\mathbf{1 5 0 . 0 7}$ & $\mathbf{2 . 7 4}$ & $\mathbf{1 3 1 . 9 3}$ & $\mathbf{6 7 . 3 7}$ & $\mathbf{1 7 8 . 6 1}$ & $\mathbf{3 . 1 3}$ & $\mathbf{1 5 0 . 2 2}$ \\
\hline
\end{tabular}

Analysis of predicted indicators for VAT showed the growth in 2025 as compared to 2015:

1) For conservative scenario:

- $\quad$ of "invoiced VAT" indicator by 137.73 times, or $37,73 \%$;

- of "paid VAT" indicator by 123.94 times or $23.94 \%$;

2) For innovational scenario:

- of "invoiced VAT" indicator by 150.07 times or $50.07 \%$;

- of "paid VAT" indicator by 131.93 times or $31.93 \%$;

3) For forced scenario

- of "invoiced VAT" indicator by 178.61 times or $78.61 \%$;

- of "paid VAT" indicator by 150.22 times or $50.22 \%$.

Thus, we showed vividly the possibility for use of correlation-regression analysis for forecasting of the volume of value added tax on the basis of macro-economic indicator of GDP.

\section{Conclusions}

3.1 Conduct of correlation-regression analysis allowed allocating the presence of vivid dependence between "paid I invoiced" VAT and GDP.

3.2 Comparative analysis of calculated coefficients of correlation shows stronger connection between GDP and invoiced VAT than between GDP and paid VAT, which proves multiple conclusions of the Russian researchers on problems of administration of this tax in Russia.

3.3 Based on the daft of correlation-regression analysis, the predicted model of development of the level of VAT until 2025 was built.

3.4 Use of correlation-regression connection of indicators of GDP and VAT allows receiving predicted values of revenues of the value added tax into the state budget on the basis of predicted values of macro-economic indicator of gross domestic product.

\section{References}

Anisimov S.A., Ostapenko V.V., Pogorelko I.A., Problems of forecasting tax revenues // Audit and financial analysis 2003'1 http://www.auditfin.com/fin/2003/1/fin_2003_01_rus_01_04_Anisimov/fin_2003_01_rus_01_04_Anisimov.asp

Astafyeva E., Saakyan R. Forecasting tax revenues with the use of structure models // Problems of theory and practice of management. - No. 3 - $2007-$ P.16-31.

Barulin S.V., Ermakova E.A., Stepanenko V.V. Tax management. - M: High school library, 2007 . - 272 p.

Budget Code of the RF, Chapter 22 Article 199 // Informational system "KonsultantPlus". - Access: http://www.consultant.ru.

Grishchenko A.V. Evaluation of tax potential of the region //Financial management No. 4, 2013, P. $62-73$

Korostrelkina I.A., Methodology of planning and forecasting tax revenues in view of influence of debt for taxes and charges http://www.upruchet.ru/articles/2011/3/5676.html

Kremer N.S. Econometrics: textbook for university students [Text] / N.S. Kremer, B.A. Putko; ed. by N.S. Kremer. $-3^{\text {rd }}$ edition. - M.: UNITI-DANA, 20

Lermontov, Y. M. Forecasting budget revenues from VAT [Text] / Y. M. Lermontov.// Tax bulletin. - 2004. - No. 11. - P. 6 - 9. 10. - 328 p.

Tax statistics and analytics [E-source] / Official web-site of the Federal Tax Service URL: http://www.nalog.ru/rn34/ date of access 11.04.2014

Okun A.S. Methodology of forecasting tax revenues under the conditions of representative tax system of the RF/l Modern scienceintensive technologies, p. 24-30

Official web-page of the Government of the Russian Federation [E-source] / Access: http://government.ru/orders/4197/. Date of access 15.04.2015

Forecast of long-term socio-economic development of the Russian Federation until 2030 [E-source] / Access: http://www.consultant.ru/ document/cons_doc_LAW_144190/ Date of access 12.04.2015.

Protasiv Y.M. Modeling of interconnections of macro-economic indicators with means of correlation-regression analysis/Bulleting of 
Moscow State Oblast University No. 2, 2012, P. 177-181

Ryabkov I.L. Use of multi-factor regression analysis for the forecast of tax revenues//Economy and business: theory and practice. No. 3 , Year: 2015 P.: 49-52

Slepneva L.R. Evaluation of tax potential of region on the basis of various methods//Bulletin of VSGUTU No. 1 (36), 2012, P. 25

Timirkhanova L.M., Zhuravleva Y.Y. Forecast of tax revenues of the budget and its improvement//Finances and accounting: Problems of methodology and practice, №. 1-3, 2013, P. 98-110

Federal law dated December 1, 2014, No. 384-FZ "On federal budget for 2015 and planned period of 2016 and 2017". - [E-source] Access (ed. On November 27, 2013): http://www.consultant.ru/document/cons_doc_LAW_178412/.

Cherkharova, N. I., Evaluation of parameters for choosing the equation of trends for the forecast of tax revenues into regional budget for statistical and expert information //Issues of modern science and practice. V.I. Vernadsky University, No. 7-9, 2010, P. 58-65. 